\title{
Searching for a symbolic shipwreck in Table Bay: Haarlem (1647)
}

AUTHORS:

Bruno E.J.S. Werz',

Willem H.B. Steenkamp ${ }^{1,3}$

Mark R. Prowse 1,4

\section{AFFILIATIONS:}

${ }^{1}$ African Institute for Marine

\& Underwater Research,

Exploration and Education

(AIMURE), Cape Town,

South Africa

2Department of History and Heritage Studies, University of Pretoria, Pretoria, South Africa ${ }^{3}$ BroadBand Geophysical (Pty) Ltd, Shelley Point, South Africa

${ }^{4}$ Underwater Surveys (Pty) Ltd, Cape Town, South Africa

\section{CORRESPONDENCE TO:}

Bruno Werz

\section{EMAIL:}

ceo@aimure.org

\section{KEYWORDS:}

Dutch East India Company; geophysical survey; Dolphin Beach; South Africa

\section{HOW TO CITE:}

Werz BEJS, Steenkamp WHB, Prowse MR. Searching for a symbolic shipwreck in Table Bay: Haarlem (1647). S Afr J Sci. 2017;113(9/10), Art. \#a0227, 4 pages. http:// dx.doi.org/10.17159/sajs.2017/ a0227

\section{(c) 2017. The Author(s).}

Published under a Creative

Commons Attribution Licence.
When on 25 March 1647 the VOC ship Haarlem stranded in Table Bay, nobody expected that this incident would become the catalyst that created one of the roots of current multiracial and multicultural South African society. ${ }^{1}$ Of the ship's crew, 58 were repatriated soon after stranding, but 62 men stayed behind to try and salvage as much of the cargo as possible. During their sojourn, the men from Haarlem came into contact with indigenous people. Upon returning to the Netherlands, the crew reported favourably of their experiences. As a result, VOC management decided to establish a much-needed stopover for its ships that later developed into the City of Cape Town. Although no conclusive physical evidence of the wreck has yet been obtained, the multidisciplinary approach followed in an effort to locate the wreck of the Haarlem is reported here.

The basis is provided by historical information that is contained in archival documentation. Of particular importance are contemporary eyewitness accounts, as contained in part of a journal that was kept by the junior merchant from the Haarlem, Leendert Jansz, and associated correspondence. ${ }^{2,3}$ Jansz was put in charge of the salvage attempts that followed the wrecking. Additional information could be abstracted from a report by commissioners who visited the wreck during the course of 1647 ; details provided by the commander of the fleet that repatriated the remainder of the crew in 1648; accounts by the first commander of the settlement at the Cape, Jan van Riebeeck; as well as a contemporary published description of the Cape of Good Hope. ${ }^{4-8}$

\section{Wreck location}

The documents provide information on the approximate location of the incident. A report, dated 29 August 1647 and compiled by officers from the ships Tijger, Henriette Louise and Noord Munster who visited during a stopover, indicates that: ' ...Haerlem... stranded at the north side of this bay'4. Another reference is provided by Jodocus Hondius III (1622-1655) who in 1652 stated: ' . . the bight that is called the bight of Sardanje, which is the east side of Table Bay. In the year 1647, the ship Haarlem beached in this bight... past and to the north of the Salt River'8. An accompanying map, showing the coastline from St Helena Bay to Cape Hangklip, indicates the 'Bogt van Sardanje' at the eastern side of Table Bay, to the south of the rock outcrops near present-day Blaauwberg, to the southeast of Robben Island and north of the Salt River.

Additional evidence as to the approximate place of foundering is provided by cartographic material that is lodged in the Nationaal Archief in The Hague. The first of these documents is a so-called fair sheet which contains a sketch of the Table Bay area, orientated to the west, together with soundings, indications of suitable anchoring grounds and coastal profiles of the surrounding mountains (Figure 1). ${ }^{9}$ On this document, the approximate location where the wrecking took place is indicated by a description near the northeast coastline of Table Bay: 'Approximately at this place the ship Haerlem stayed'. As the curve of the eastern coastline on this document is exaggerated, an electronic copy was manipulated to obtain a best fit to coincide with the actual situation. This was accomplished by enlarging and distorting the fair sheet to overlay identifiable marks over the same marks on a modern South African Navy chart of the area. ${ }^{10}$ The results of this manipulation indicate a position for the wreck close to or on shore, to the southeast of Robben Island and in the vicinity of present day Table View - Dolphin Beach.

Two other contemporary images were traced that provide indications for the situation during the $1650 \mathrm{~s} .{ }^{11,12}$ These manuscript maps indicate the location of the wreck in the northeastern section of the Table Bay area, as being either $\mathrm{on}^{11}$ or very close ${ }^{12}$ to the beach and opposite an area inland with salt pans. This position is confirmed by Van Riebeeck. In an entry in his journal, made on 20 May 1652, he states: 'Paid a visit to the wreck of the ship Haerlem which we saw still buried in the sand. ... salt, which we found in fair abundance in that vicinity...' ${ }^{6}$. Nearly 7 years later, his journal reports that on 29 January 1659:

....at the mouth of the river which...our explorers called Hollands Rietbeecq [Diep River]. At its mouth this river is dry at present, but in the rainy season it flows strongly into the large salt-pans above the wreck of the Harlem (sic) at the tail of the Leopard Mountain, and then from there, through the pans, into the Salt River. ${ }^{7}$

These salt pans are also mentioned in Hondius Klare besgryving:

Three or four miles up this Salt River there is a large patch of sand on which, in hot, dry weather sometimes so much pure white salt crystallizes (a hand's breadth deep), that it would be possible to take away a shipload of it. ${ }^{8}$

The area that contained these salt pans is indicated on a map of Table Bay and the adjacent east coast by Joannes van Keulen II (1704-1755). ${ }^{13}$ The map dates to 1753 and is very accurate, as was proven by overlaying it with the SA Navy chart 118 of Table Bay (Figure 2). ${ }^{10}$ The overlay also made it possible to project the 17 th and 18 th northern and southern perimeters of the salt pans on the current situation. This shows that the northern boundary, when drawn along an east-west line, runs straight through the present Dolphin Beach Hotel in Table View. The southern line cuts across the northernmost houses in Milnerton. From this reconstruction it can also be concluded that the greater part of the old salt pans are currently covered by the Rietvlei Lake. 


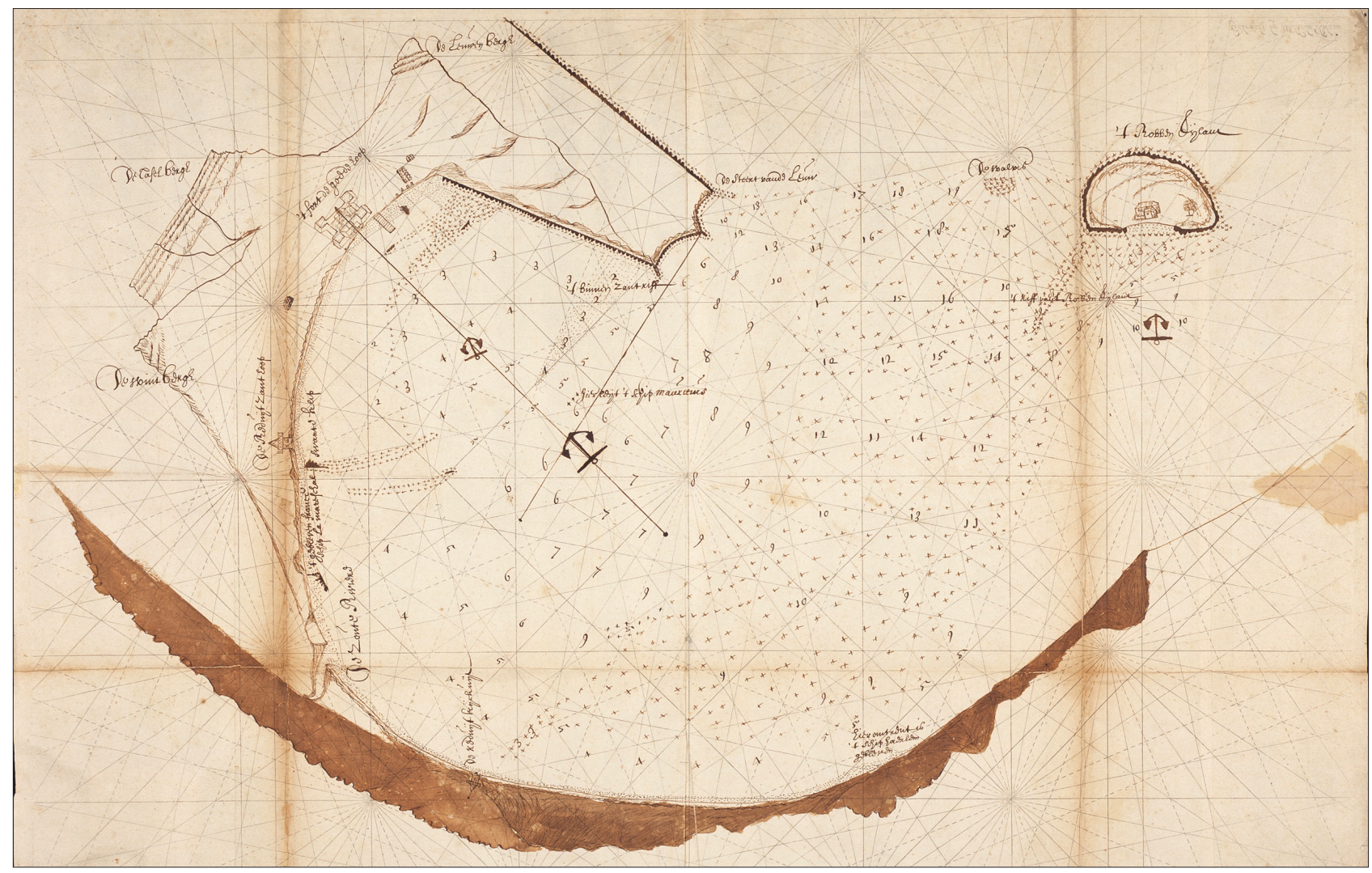

Nationaal Archief, The Hague, the Netherlands.

Figure 1: Fair sheet of Table Bay, dating to 1663, with the approximate position of the Haarlem wreck marked.

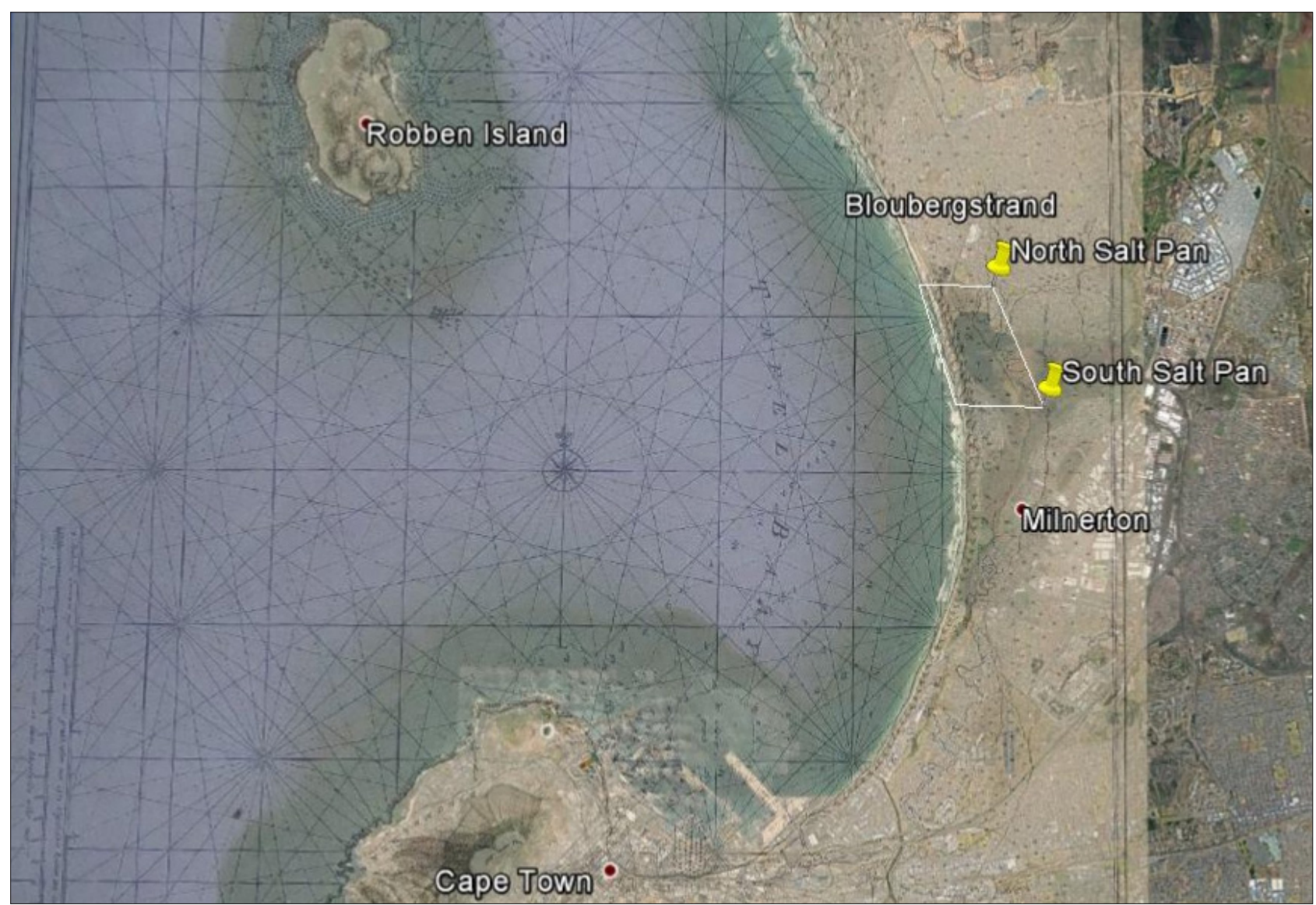

Photo: Mark Prowse @AIMURE

Figure 2: Map of Table Bay and the adjacent coast, by Joannes van Keulen, dating to 1753, overlaid with SAN chart 118, Table Bay. 
In the journal of Leendert Jansz, the place of foundering was recorded at a distance of: ' $11 \frac{1}{2}$ mile...from the Table Bay'3. It may be assumed that 'Table Bay' in this context refers to the old roadstead or the adjacent landing place, close to the location where the first official Dutch fort was constructed in 1652. At the time, 15 geographical Dutch miles equaled one degree of longitude on the equator. A standard of $7408 \mathrm{~m}$ for 1 Dutch mile was thus maintained for another reconstruction based on the length of one degree, which equals an average distance of $111.12 \mathrm{~km}$. Taking the approximate location of Van Riebeeck's fort as a base, a distance of $11112 \mathrm{~m}$ was plotted in a straight line across Table Bay. The end point of this line touched the coast at Dolphin BeachSunset Beach, directly opposite Rietvlei. Using the same starting point, another line with a distance of $11112 \mathrm{~m}$ was projected following the old coastline as close as possible. This line ended slightly to the south of this point but still on Sunset Beach.

\section{Geophysical surveys}

A limited geophysical survey was undertaken during 2015, followed by a second phase that was undertaken during October-November 2016. During this last exercise, the full length of the permit area in the intertidal zone was covered, resulting in a total survey length of $25949 \mathrm{~m}$. The survey lines were approximately $10 \mathrm{~m}$ apart and the average magnetic sampling interval along the lines was approximately $1.2 \mathrm{~m}$. Significant anomalies were scanned in greater detail by increasing the number of lines covering the areas of special interest. The results of this analysis, combined with additional information acquired since the start of the Haarlem project in 1989, indicate the following.

Two anomalies detected during the 2015 geophysical survey are caused by natural intrusive rocks - so-called dykes - containing magnetite. These dykes are clearly indicated by the countrywide airborne magnetic data set. ${ }^{14}$ Geophysical modelling indicates the width of the dykes to be 10-20 m, with the tops of the dykes at depths of approximately $-25 \mathrm{~m}$. An anomaly found in between the dykes during the 2015 survey is probably caused by relatively modern refuse. During the 1970s, developments in Cape Town harbour necessitated sand winning. To that purpose, a pipeline was constructed from the harbour area along the beach to Rietvlei. It is thus quite possible that the anomaly is caused by pipes and other ferrous items that were not removed at the time. ${ }^{15}$

Other signals recorded in 2016 are caused by a power line or a pipeline in the northern section of the survey area or result from many additional anomalies, indicating that the sub-surface beach is littered with ferrous objects. Most of these anomalies have small footprints and geophysical modelling suggests that the ferrous objects are relatively shallow $(<2 \mathrm{~m})$ and probably weigh less than $20 \mathrm{~kg}$. These are therefore judged to be low priority targets. However, there are five areas (A-E on Figure 3) where more significant anomalies with larger footprints occur. Geophysical modelling of these anomalies indicates the probable presence of ferrous objects of significant volumes that lie at depths of approximately $3-4 \mathrm{~m}$. Figure 4 illustrates an example of the magnetic data that cover one of the principle target areas.

Although the wreck of the Haarlem has not been found to date, strong leads as to its approximate location have been obtained. Based on the available information, it can be concluded that the ship stranded in the northeastern section of Table Bay, specifically the Dolphin Beach-Sunset Beach area, opposite or very close to Rietvlei. The wreck must either be underneath the intertidal beach, or be in very shallow water at the foot of the beach. The geophysical surveys undertaken to date have indicated a number of anomalies. These anomalies are partly caused by geological features or are of an anthropogenic origin.

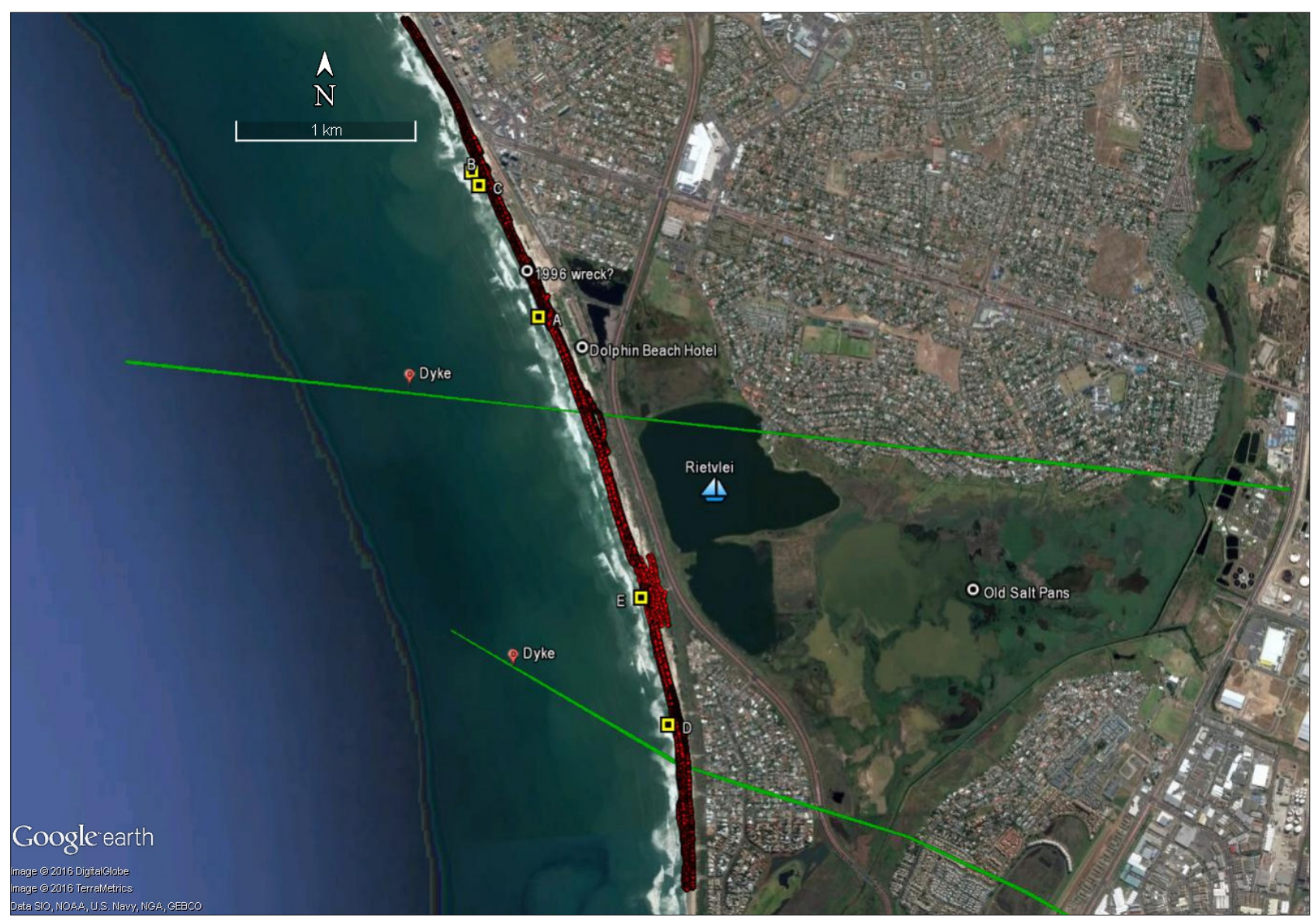

Photo: Billy Steenkamp @)AIMURE

Figure 3: Overview of the search area with five principal targets that need further investigation. 


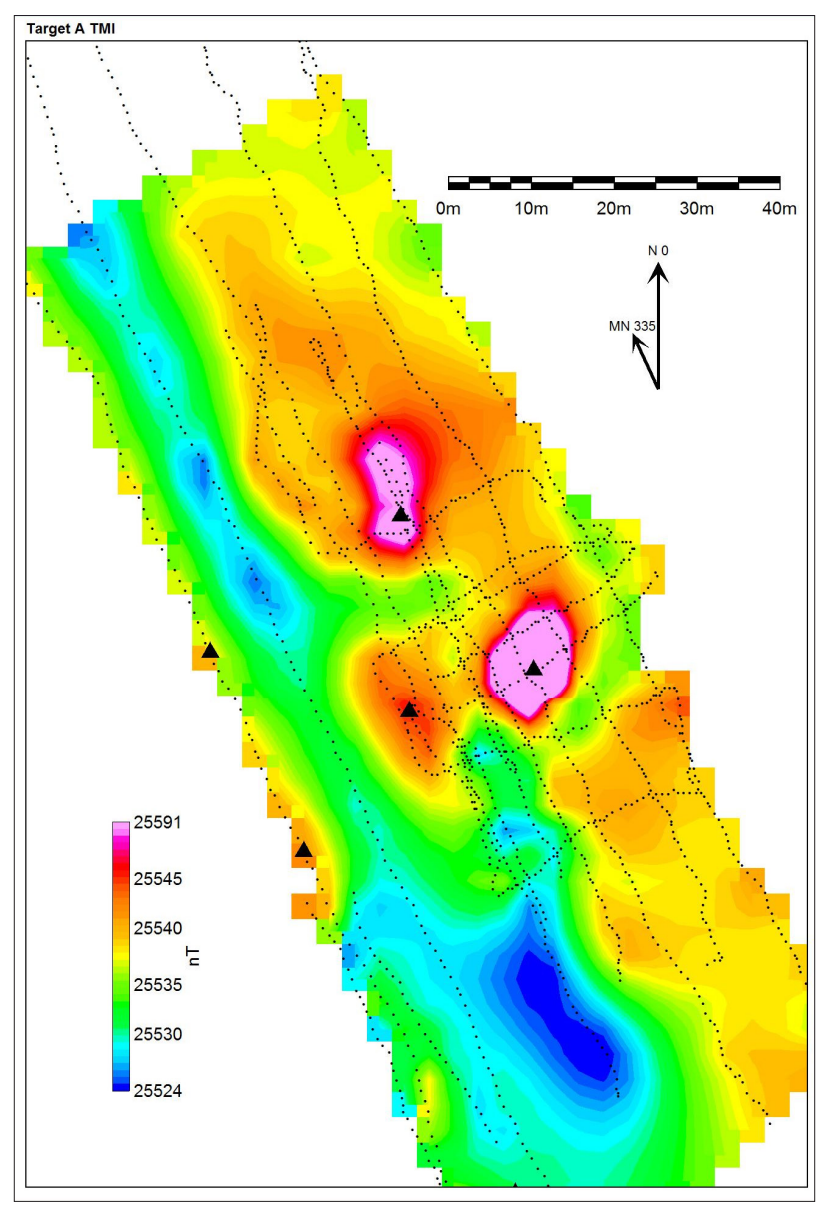

Photo: Billy Steenkamp (CAIMURE

Figure 4: Detailed magnetic survey of the principal target area, immediately to the west of the Dolphin Beach Hotel.

Five anomalous areas were recorded that indicate the probability of buried wrecks. One of these was found slightly north of the Dolphin Beach Hotel and this site was excavated by one of us (B.E.J.S.W.) in 1996. This wreck could not be identified at the time. Nevertheless, copper hull sheeting indicated its earliest period of construction as towards the end of the 18 th century. Copper sheeting was only introduced from about the 1780s onwards, to prevent fouling of ship's hulls and to prevent deterioration caused by marine borers. The same applies to another wreck of which fragments were found after the American container vessel Sealand Express that stranded on Sunset Beach in August 2003 was pulled off. This is probably the same anomaly as indicated by Figure 3 , point $D$.

An inventory of historical shipwrecks in the Blaauwberg, Table View, Rietvlei and Milnerton areas was compiled, using a variety of archival documents and other references. ${ }^{16-20}$ The records indicate that at least 34 shipwrecks occurred in the area of interest. This number may possibly be higher, as at least 94 wrecks occurred in the Table Bay area for which the place of foundering is not specified..$^{20}$ Of the 34 wrecks whose approximate location is known, one dates to the 17th century (Haarlem, 1647). This ship is recorded as having foundered near the Table View-Sunset Beach-Milnerton area. Two shipwrecks dating to the 18th century (La Cybelle, 1756 and Severe, 1784), are reported to have been lost near Blaauwberg, further to the north. These ships would not have had copper sheeting on their hulls, with the possible exception of the Severe. The later wrecks - 31 of them - are spread over both areas and they would have either had hull sheeting or been constructed of iron. Once found, the Haarlem can be positively identified based on its location and because its hull was not fitted with copper sheeting. Furthermore, the wreck should still contain the remains of 19 iron cannons and four anchors, as indicated by the historical record. ${ }^{5}$

\section{Acknowledgements}

We thank the Board and Dive Unit of the African Institute for Marine and Underwater Research, Exploration \& Education (AIMURE); Edwin Mills; BroadBand Geophysical; Ephan Potgieter and Andrew Matthews of Underwater Surveys; Allen Wood of the Koeberg Nuclear Power Station; Tristan Mostert of the Atlas of Mutual Heritage and Thomas Dresscher of the Nationaal Archief, the Netherlands; Professor Susan Webb and Dr Sharad Master of the School of Geosciences, University of the Witwatersrand; and Dr Pieter Kotze and Emmanuel Nahayo of the South African National Space Agency for their support and assistance. This survey was entirely sponsored by AIMURE, BroadBand Geophysical (Pty) Ltd and Underwater Surveys (Pty) Ltd.

\section{References}

1. Werz B. The Haarlem shipwreck (1647): The origins of Cape Town. Pretoria: Unisa Press; 2017.

2. Nationaal Archief, The Hague, Archive of the United East India Company (VOC) 1166. Overgekomen brieven en papieren uit Indië aan de Heren XVII en de kamer Amsterdam, 1648, tweede boek, vervolg [Letters and documents sent from the Dutch East Indies to the VOC directors and the regional office of Amsterdam, 1648, second volume, continuation]. Dutch.

3. Western Cape Archives. Verbatim copies (VC) 284, Journal and letters of Leendert Jansz after the wreck of the ship 'Nieuw Haarlem' at the Cape, 1647.

4. Western Cape Archives. VC 284, nr. 6. Rapport, bijde Gecommitteerde vande gem[elde] scheepen gedaen, over haere gedaene visite aen Cabo de Bona Esperance, bij die vant [ver]ongeluckte schip Haerlem [Report by the commissioners of the mentioned ships, regarding their visit at the Cape of Good Hope to those of the wrecked ship Haerlem]. Dutch.

5. Nationaal Archief, The Hague. VOC Collection Wollebrant Geleynse de Jong 1.10.30.

6. Van Riebeeck J. Journal of Jan van Riebeeck I. 1651-1655. Thom HB, editor. Cape Town/Amsterdam: A.A. Balkema; 1952.

7. Van Riebeeck J. Journal of Jan van Riebeeck III. 1659-1662. Thom HB, editor. Cape Town/Amsterdam: A.A. Balkema; 1958.

8. Hondius J. Klare besgryving van Cabo de Bona Esperanca, 1652 [Clear description of the Cape of Good Hope, 1652]. Dutch.

9. Nationaal Archief, The Hague, Collection Leupe nr. 178. Kaart van de Tafelbaai, het Robben Eiland, de Klip de Walvisch, benevens aanwijzing waar eenige schepen gebleven zijn, 1663 [Chart of Table Bay, Robben Island, Whale Rock, as well as indications where some ships foundered, 1663]. Dutch.

10. South African Navy. Chart 118. Table Bay. 1:150.000 National series.

11. NA VEL 0803. In: Atlas of Mutual Heritage [database on the Internet]. Available from: http://www.atlasofmutualheritage.nl/en/

12. NA VEL 0804. In: Atlas of Mutual Heritage [database on the Internet]. Available from: http://www.atlasofmutualheritage.nl/en/

13. Van Keulen J. Kaart van de Tafelbaay vertoonende de reede van C. de Goede Hoop 1753 [Map of Table Bay showing the roadstead of the Cape of Good Hope 1753]. Dutch.

14. Council for Geoscience. Open file $1 \mathrm{~km}$ line-spacing dataset.

15. South African Railways and Harbours. Table Bay harbour. Harbour extension stage 2. Rietvlei borrow pit general layout, sheets 1-4, 29-7-1971. Cape Town: South African Railways and Harbours; 1971.

16. South African Library. List of South African shipwrecks. 1990. Unpublished.

17. Marine casualties southern African waters 1552 to 1913. S Afr Ship News Fish Ind Rev. 1982;37(6):18-42.

18. Marine casualties southern African waters 1914 to 1945. S Afr Ship News Fish Ind Rev. 1983;38(6):3-13.

19. Marine casualties southern African waters 1946 to 1984. S Afr Ship News Fish Ind Rev. 1984;39(6):3-27.

20. Werz BEJS. Strategic environmental assessment (SEA) for the Port of Cape Town and environmental impact assessment (EIA) for the expansion of the container terminal stacking area. Specialist study in maritime archaeology. Stellenbosch: CSIR Environmentek; 2003. 